\title{
RSP Revisitada Caminhamos para o impôsto único?
}

Texto publicado na RSP, Ano 7, maio de 1944 (vol. 2 - n 2)

José Saldanha da Gama e Silva

Sentimos de antemão o sorriso altamente irônico que o leitor pespegará nos lábios ao receber a pergunta em epígrafe. Ora, pensará, mas então isso é pergunta que se faça?! Não está aí o exemplo de Henry George, relegado ao escárnio dos séculos precisamente porque teve a "genial" idéia de pregar durante sua vida de cientista o impôsto único sôbre o rendimento da terra?! Se retrucarmos que vamos tratar apenas do impôsto sôbre a renda, ainda nos lembrará, prestimoso: não está aí o exemplo mais recente de Bartolomeo Benvenuti, que tem recebido apupos de tôda a Itália, porque em seu II Sistema dei Tributi pregou nada mais nada menos que o impôsto único sôbre a renda?! E, além do mais - ajuntará ainda o leitor intransigente - Seligman, o corifeu non plus ultra de tal matéria, já não situou inflexivelmente a questão, esclarecendo terminantemente no final de seu artigo inserto na Encyclopaedia of the Social Sciences - com ênfase de quem encerra vez por tôdas uma querela - que "o impôsto sôbre a renda não pode ser mais que um dos elementos de um sistema tributário plural"? 
É certo que não ignoramos a falência do "georgismo" nem as razões ponderáveis de Seligman. Exposto francamente às flutuações econômicas, o impôsto sôbre a renda reflete com agravos suas consequências, ora tendo a produtividade acelerada em tempos de folga, ora quase se anulando em tempos de depressão, afligindo o Govêrno justamente no momento em que o Tesouro devia estar saciado para atender às necessidades da conjuntura, tais como as decorrentes do fenômeno do desemprêgo, astenia de circulação, etc. Sabemos também que baseados nestas razões é que tratadistas renomados, clássicos ou jovens, como Vito Bompani ${ }^{1}$ e Clyde L. King ${ }^{2}$, atestam para o impôsto sôbre a renda um papel de simples "suplemento" - que, afinal, não está muito longe do obsoleto caráter de mero "complemento" com que o pioneiro Leroy Beaulieu espartilhou o tributo.

É verdade que de tudo isto estamos informados; mas, apesar de tôdas estas ponderações, baseados na análise repetida de alguns fenômenos respigados pela linha evolutiva do tributo, reiteramos a dúvida: afinal, caminhamos para o impôsto único sôbre a renda?

Eis por que, talvez com o intuito sádico de lançar o leitor desavisado nesta mesma situação de expectativa, não titubeamos em alinhar aqui algumas das razões que nos deixaram cum granum salis, não obstante tôda a celeuma negativista que se tem feito em tôrno da falência do impôsto único.

A história do impôsto sôbre a renda é a própria história da tributação: se muito apurarmos o conceito de renda, chegamos maravilhados à conclusão de que outra coisa não fizeram os mais antigos povos que, tentando aperfeiçoar seus sistemas tributários, acercar-se cada vez mais do impôsto sôbre a renda. Êste é o exemplo da éisphora na Grécia do século IV antes de Cristo, da lustralis collatio, da Roma decadente, ou da décima scalata, da Florença do pré-renascimento - isto sem levar em conta a palavra de alguns autores mais gulosos $^{3}$ que, indo mais longe, chegam a surpreender o impôsto no Egito de 1580 A.C. É sabido, porém, que, na sua atual caracterização, o impôsto sôbre a renda surgiu apenas em 1798, resultado de sucessivos conchavos fiscais que o gênio político de Pitt concebera. É certo também que a história de sua evolução remonta mais longe, principalmente à longa experiência da taille francesa que, esbordada por tôda a Europa, iria pressurosa acomodar-se a todos os sistemas fiscais surgentes com a criação dos primeiros grandes estados organizados; mas não é menos certo que suas lutas pela hegemonia nos esquemas financeiros começam realmente só depois de Pitt, já que apenas desde então podemos acompanhá-lo frente aos países estruturados no liberalismo.

Emergindo na época em que o liberalismo francês de todos os Laboulaye incrementava a fúria com que a técnica industrial inglesa ia forjando o capitalismo conservador; florescendo na época em que o capitalismo essencialmente comercial baqueava redondamente em tôda a Europa, o impôsto sôbre a renda - criado para o custeio da guerra contra Napoleão e eternizado para compensar as iniqüidades dos impostos indiretos - vai afirmarse paulatinamente, reagindo em primeiro lugar contra os impostos de consumo, e, depois, contra todos os impostos indiretos.

Realmente, a partir do século XVIII, quer na Holanda, quer na Inglaterra - países em que inicialmente se consolidou a economia individual - os impostos indiretos, depois de seu apogeu continental, começam a mostrar, além de suas flagrantes 
iniqüidades, tôda sua comprometedora incapacidade frente aos grandes acúmulos de capital. Assim, os impostos diretos vão substituindo os indiretos não apenas pelas razões alegadas pelo otimismo de alguns historiadores - segundo os quais a substituição se processou em função dos exemplos das clamorosas injustiças dos excises, cises etc., sempre de traslação "misteriosa" - mas porque o fisco descobrira novamente ser a tributação direta $\mathrm{O}$ caminho mais curto para a saciedade de suas arcas. Dêsse modo, se a gabelle tem uma honrosa tradição na história da declaração dos direitos do homem, é lícito reconhecer sua impotência para, com a fôrça de suas iniqüidades, torcer sozinha a diretriz dos tentáculos do fisco.

Eis por que não se pode hoje pensar que o impôsto sôbre a renda vingou apenas porque as desvantagens dos impostos indiretos lhe facilitaram um pundonoroso repúdio por parte dos fiscos europeus. Longe disso: de nada adiantariam todos os fenômenos de traslação dolosa a que estão sujeitos os impostos indiretos - principalmente os de consumo; de nada adiantariam as côres maciamente filantrópicas que a ciência tributária começava a tomar, se o fisco não encontrasse nos impostos diretos um sucedâneo hábil para a tributação indireta. Os impostos diretos - principalmente o de renda - venceram, pois, os quadros tributários, apenas quando o fisco, pela natural evolução da ciência financeira, pôde mostrar-se sem rebuços - ambicioso, sem rapina; exigente, sem despotismo.

Já então a renda se mostrara o mais perfeito instrumento para a mensuração da capacidade contributiva de cada cidadão. Levada a verdadeiros requintes de subjetivismo analítico, a renda passou a agir como aquêle índice infalível da capacidade de suportar o ônus fiscal, demarcando com precisão matemática a margem de sacrifício conveniente para cada caso pessoal.

Dêsse modo, por uma reversão sistemática de fatores injuncionais, o fisco passa da capitação simples à capitação graduada; da pessoa do contribuinte à fortuna respectiva; do indistinto acervo de bens ao fluxo de satisfações que é, afinal, a renda.

Dentro de tôda esta difusa causalidade histórica responsável pela hegemonia final

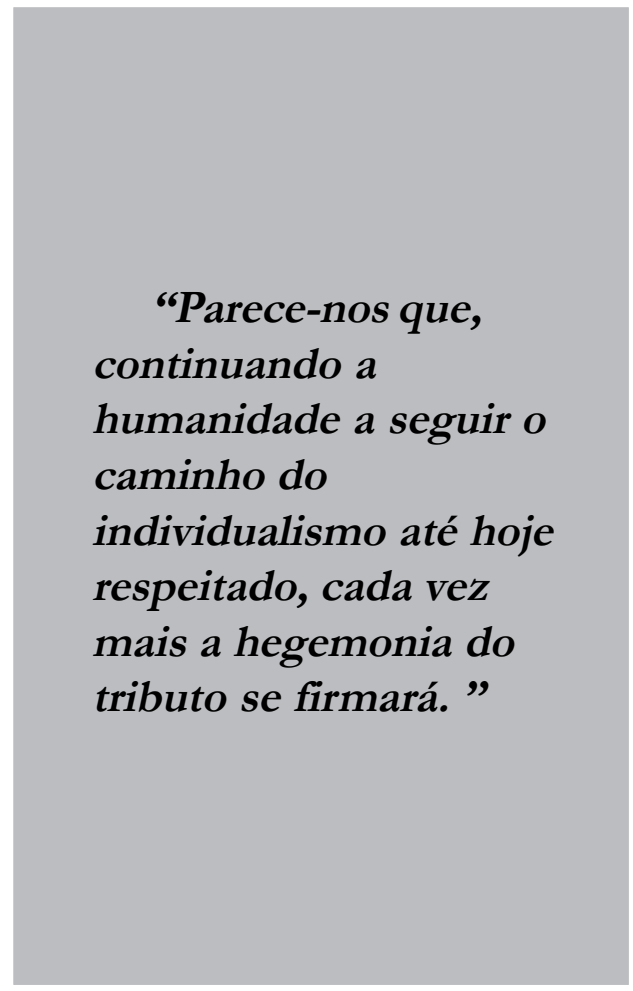

do impôsto sôbre a renda nos modernos quadros financeiros, podemos vislumbrar com pequeno esfôrço alguns estágios precursores desta situação atual.

Abandonando o período em que o tributo foi mero recurso de guerra, podemos surpreender um primeiro estágio em que o impôsto sôbre a renda se vai insinuando nos quadros tributários para compensar as iniqüidades dos impostos 
indiretos - ou diríamos melhor, para obstar que os impostos indiretos se extremassem indefinidamente em iniqüidades crescentes. É a época de quando em França as cises vão deixando lugar aos dixièmes e vingtièmes, embora o Estado explorasse à socapa a cornucópia da gabelle.

Com a expansão irreprimível do industrialismo inglês e a conseqüente eclosão do livre cambismo, o income-tax de Pitt-solenizado pelos coros socialistas que David Hume, Adam Smith, Malthus e outros compuseram em surdina - foi vencendo as oscilações do capitalismo inglês, ora manipulado por Peel, ora por Gladstone ou Disraeli. Afirmando-se vigorosamente, o impôsto sôbre a renda, afinal, deixa de ser um mero complemento dos impostos indiretos para chegar à situação de seu vero competidor. É a época em que a Grã-Bretanha passa a equilibrar todo seu arcabouço fiscal no jôgo habilidoso do tea-duty versus income-tax.

A partir do início do século XX vai afinal o impôsto sôbre a renda galgar as culminâncias de impôsto básico dos sistemas tributários mais complexos. Valorizado pela teoria sócio-política dos impostos que o gênio de Wagner concebera, cristianizado pelas vantagens que o princípio da progressividade - então assaltado pela propaganda intensiva dos mais preclaros financistas - estava fartamente prodigalizando, o impôsto sôbre a renda, amplamente manejado pelos países atingidos pela guerra de 1914, terá sua percentagem a subir celeremente em face das receitas gerais. Assim, se a Itália, logo após o conflito, via a produtividade da imposta sui redditi della riccheza mobile subir a 40\%, a Grã-Bretanha, já em 1925, usufruía um income-tax que lhe rendia $50 \%$ da receita total. E não apenas nestes países o exemplo se repetia: uns após outros, todos os grandes países vão seguindo as pegadas inglesas, inclusive o Brasil, que já neste ano corrente terá no impôsto sôbre a renda a coluna-mestra de seu arcabouço tributário.

O desenvolvimento contínuo do impôsto sôbre a renda foi tornando-o mais e mais complexo. Se o income-tax lançado por Pitt já era uma confusa miscelânea de assessed-taxes, o impôsto de nossos dias é um acúmulo mais ou menos indistinto de pequenos impostos parciais. Se já em 1853 Gladstone, num dos seus famosos relatórios, chamava a atenção para a difícil "composição" do income-tax ${ }^{4}$, hoje podemos ultrapassá-lo e atentar no verdadeiro sistema de tributos que é o atual impôsto sôbre a renda. Basta observarlhe os modernos aparelhos em diversos países para tal assertiva ficar plenamente justificada.

Nos Estados Unidos, por exemplo, o impôsto subdivide-se ora com referências às pessoas físicas, ora com referência às pessoas jurídicas, passando do current-individual ao victory-tax; do current-corporation aos excess-profits-taxes - isto sem falar nos pequenos impostos mistos.

$\mathrm{Na}$ Grã-Bretanha, a subdivisão ainda vai mais longe: postado em 3 grandes grupos $\mathrm{o}$ da Taxation of IndividuaIs, o da Taxation of Business-Profits e, mais recentemente, o da Post War Credits -, o income-tax fragmenta-se difusamente, na ânsia de surpreender a renda nos mais recônditos jogos das relações humanas.

No Brasil, aí está o tributo dividido em taxas, sôbre-taxas, cédulas e proporções - sem falar-se no novel impôsto sôbre lucros extraordinários, verdadeiro apêndice do primeiro.

Nota-se, pois, atualmente, uma tendência irreprimível para a expansão do tributo mundo em fora, perdendo-se o gravame em ininterruptas cissiparidades, 
bifurcações e entrelaçamentos - numa fragmentação constante que vai tornando o tributo mais e mais distendido, embora mais e mais "capilarizado".

Tantas e tão fundamentais têm sido as transformações por que vêm passando os cânones da ciência tributária que não será desarrazoado julgar-se que, em evoluindo os fenômenos financeiros na mesma linha ascensional seguida até hoje, o impôsto sôbre a renda se tornará inapelavelmente a coluna-mestra de todos os sistemas fiscais. Não são apenas as contingências da guerra que, nos Estados Unidos, elevaram o produto do income-tax, no período 1940/ 1941, a 72,23\% da receita geral do país. É que as vantagens da tributação sôbre a renda já vão hoje tomando foros de venerandos lugares-comuns. Sua extrema flexibilidade, sua natural periodicidade, sua opulenta facilidade de democratização, são todos pontos exaustivamente ventilados pelos autores especializados na matéria: de Seligman a Bompani, de Paul Strayer a Just Haristoy.

Por estas razões, parece-nos que, continuando a humanidade a seguir o caminho do individualismo até hoje respeitado, cada vez mais a hegemonia do tributo se firmará.

Como, porém, se comportará o tributo nos próximos anos? Usando dos jogos caprichosos da imaginação, tentemos responder a esta pergunta.

De início, podemos prever para um futuro não muito remoto a inversão completa da situação anteriormente criada pelo fisco: os impostos indiretos, à medida que o impôsto sôbre a renda fôr crescendo, passarão a ter importância cada vez menos fundamental nos grandes quadros tributários. $\mathrm{E}$ veremos então que tais impostos subsistirão apenas para, como já pregou Sir Josiah Stamp ${ }^{5}$, gravar de modo tosco as pequenas rendas, arredias ao impôsto direto sôbre a renda. Assim, dia virá em que algum futuro Leroy Beaulieu descobrirá sisudo que os impostos indiretos devem ser usados apenas como complementos dos impostos diretos, ou, melhor, como "elementos compensadores das iniqüidades do impôsto sôbre a renda".

E então estará visceralmente fendida a base da tributação indireta. À medida que o aparêlho do impôsto sôbre a renda se fôr mais e mais aperfeiçoando, suas iniqüidades - já hoje tão diminutas - irão menos e menos dependendo de impostos que as compensem. Dêsse modo, após um período, naturalmente breve, em que os impostos indiretos serão singelos impostos subsidiários do impôsto sôbre a renda, virá o período em que se dará fatalmente a absorção daqueles pela crescente complexidade do sistema dêste último. Por essa época, talvez não mais tenhamos os impostos indiretos com a precisão discriminadora hoje sua característica, porque antes - se fôr o caso de subsistirem - terão perdido seu aspecto atual, passando, por fim, a agir como simples manifestações indiretas do impôsto sôbre a renda. Assim, por exemplo, os impostos de consumo só subsistirão para garantia secundária da perfeição do impôsto sôbre a renda, ou, melhor: chegaríamos à situação em que, à fôrça do impôsto sôbre a renda ser onipresente, os impostos de consumo acabariam por perder seus atuais característicos, terminando por serem usados como simples impostos sôbre as despesas - ou, em outras palavras - impostos sôbre a renda presuntiva.

Acrescente-se a esta situação a tendência cada vez mais evidente de alguns outros impostos, e até mesmo taxas, irem-se paulatinamente enfraquecendo até à extinção final. Não erraríamos mesmo em 
augurar o próximo desaparecimento dos direitos alfandegários. No Brasil - para exemplificar com a prata da casa - os impostos de exportação inter-estaduais, após um processo lento de estancamento progressivo, estão hoje literalmente extintos, jogando por terra as barreiras alfandegárias que, séculos a fio, entravaram o nosso progresso econômico, fenômeno que se deu também em alguns estados mais ricos, relativamente ao próprio impôsto de exportação para o estrangeiro, hoje sabidamente anti-econômico. Acresce mesmo que - levando-se em conta o ânimo entremostrado pelos dirigentes da guerra em discursos, conferências, panfletos, livros etc. - não é difícil desconfiar que as aduanas passarão a representar um papel bastante diminuto na interdependência econômica das nações do futuro - até hoje prejudicada pelos pruridos do nacionalismo mórbido.

Em outros setores, o mesmo se dará. Com o crescimento da responsabilidade estatal, as taxas irão perdendo seu valor de pagamento por determinado serviço prestado - já que cada vez mais o Estado, à fôrça de hipertrofiar-se, vai tomando o caráter de um devedor incondicional. Assim, tôda a sua capacidade de bem servir ao maior número irá gradativamente repousando apenas nos impostos - pois que só assim se acentuará indefinidamente o papel de benfeitor infalível que com tanto empenho já hoje se lhe procura dar.

Vemos, pois, que, embora dentro de uma simplificação primária de argumentos, o pensamento nos levou sorrateiramente a estas paragens inéditas: extinção futura das taxas, extinção gradativa de alguns impostos, absorção paulatina dos restantes gravames pela complexidade crescente do sistema do impôsto sôbre a renda.

Fêitas as contas, pois, sobrará apenas o impôsto sôbre a renda - não singelo e indiviso, é certo - mas, ainda assim, apenas um impôsto, embora tão complexo a ponto de exigir a categoria de vero sistema de tributos.

Afigura-se-nos, portanto, indubitável esta verdade: se tudo continuar nesta linha evolutiva que leviamente surpreendemos, o impôsto sôbre a renda caminhará a passos largos para a categoria "perigosa" de impôsto único.

Como vê o leitor intransigente, a nossa pergunta inicial parece que conseguirá ao menos levantar uma dúvida final.

\section{Notas}

1 Vito Bompani. L’imposta complementare progressiva sul reddito. Padova. 1939. Pág. 21.

2 Clyde L. King. Public Finance. N.Y. 1936. Pág. 293.

3 Lembre-se, por exemplo, Charles R. Metzger, em Brief History of Income Taxation.

4 Gladstone's Financial Statements of 1853, 1860, 1863, 1864. Londres. 1864. Pág. 20.

5 Sir Josiah Stamp. The Fundamental Principles of Taxation. Londres 1936. Pág. 74.

José Saldanha da Gama e Silva

Foi membro da Fundação Getúlio Vargas e da Comissão de Orçamento. Autor de vários livros entre eles: Os Bancos e o Estado Moderno (1952) e Tributação Sobre a Renda e Capitalismo (Editora Atlas, SP. 1946). 